\title{
Influence of sexual genotype on the behaviour of females (genotype WZ) and pseudofemales (genotype ZZ) in the tilapia Oreochromis aureus
}

\author{
Michaël Ovidio ${ }^{\mathrm{a}, \mathrm{d}, *}$, Damien Desprez ${ }^{\mathrm{b}, \mathrm{c}}$, Charles Mélard ${ }^{\mathrm{c}}$, Pascal Poncin ${ }^{\mathrm{d}}$ \\ ${ }^{a}$ University of Liège, Laboratory of Fish Demography and Aquaculture, 10, chemin de la Justice, B-4500 Tihange, Belgium \\ ${ }^{\mathrm{b}}$ ARDA, Freshwater Aquaculture Centre, ZI Les sables, BP 16-97427, Etang Salé, La Réunion, France \\ 'University of Liège, CEFRA, Education and Research Center in Aquaculture, 10, chemin de la Justice, B-4500 Tihange, Belgium \\ ${ }^{\mathrm{d}}$ University of Liège, Department of Ethology and Animal Psychology, 22, quai Van Beneden, B-4020 Liège, Belgium
}

Received 7 November 2001; accepted 21 March 2002

\begin{abstract}
$17 \alpha$-ethynylestradiol sex-reversed males of Oreochromis aureus (pseudofemales, $\Delta \mathrm{F}$, genotype $\mathrm{ZZ}$ ) are used in aquaculture to produce a male monosex population by crossing with $\mathrm{ZZ}$ homogametic normal males. When placed with males $(\mathrm{M})$ and females $(\mathrm{F})$ in the same spawning tank, the spawning rate of $\mathrm{F}$ is higher than for $\Delta \mathrm{F}$. In order to understand this phenomenon, comparisons were made between the behaviour of $18 \mathrm{~F}(446 \pm 96 \mathrm{~mm})$ and $18 \Delta \mathrm{F}(401 \pm 59 \mathrm{~mm}) . \Delta \mathrm{F}$ showed a more aggressive behaviour and were significantly more dominant than normal $\mathrm{F}$ in fighting pair experiments $(\mathrm{F} \times \Delta \mathrm{F})$ or in fighting group experiments in four different stocking densities $(8,12,16$ and 83 fish $10^{-3} 1$ with $\mathrm{F} / \Delta \mathrm{F}$ ratio $\left.=1\right) . \Delta \mathrm{F}$ were also more aggressive towards males than $\mathrm{F}$ were. The results support the idea that behavioural differences exist between $\mathrm{F}$ and $\Delta \mathrm{F}$. These differences are probably due to the effect of the sexual genotype on behaviour. (C) 2002 Ifremer/CNRS/Inra/IRD/Cemagref/Éditions scientifiques et médicales Elsevier SAS. All rights reserved.
\end{abstract}

\section{Résumé}

Influence du génotype sexuel sur le comportement de femelles (génotype WZ) et de pseudofemelles (génotype ZZ) chez le tilapia Oreochromis aureus. En aquaculture, l'inversion du sexe de mâles Oreochromis aureus au moyen d'un traitement hormonal à la $17 \alpha$-ethynylestradiol est utilisée pour produire des pseudofemelles $(\Delta \mathrm{F}$, génotype $\mathrm{ZZ}$ ) qui croisées avec un mâle homogamétique (ZZ) donneront une progéniture constituée de $100 \%$ de mâles. Cependant, lorsque des femelles $(\mathrm{F})$ et des pseudofemelles $(\Delta \mathrm{F})$ sont placées dans un même bassin avec des mâles $(\mathrm{M})$, la fréquence de ponte de femelles est supérieure à celle des pseudofemelles. Dans le but de comprendre ce phénomène, nous avons étudié le comportement de $18 \mathrm{~F}(446 \pm 96 \mathrm{~mm})$ et $18 \Delta \mathrm{F}(401 \pm 59 \mathrm{~mm})$. Dans les expériences de combat par paire $(\mathrm{F} \times \Delta \mathrm{F})$ et en groupes $\left(8,12,16\right.$ et 83 poissons $10^{-3} 1$ avec une proportion $\mathrm{F} / \Delta \mathrm{F}$ de 1$)$ les $\Delta \mathrm{F}$ se sont montrées plus agressives que les F. D'autres expériences ont montré que les $\Delta \mathrm{F}$ se montrent plus agressives que les $\mathrm{F}$ vis-à-vis de mâles. Ces expériences montrent qu'il existe des différences comportementales entre $\mathrm{F}$ et $\Delta \mathrm{F}$ qui sont le résultat de l'effet du génotype sexuel sur le comportement. (C) 2002 Ifremer/CNRS/Inra/Cemagref/Éditions scientifiques et médicales Elsevier SAS. Tous droits réservés.

Keywords: Behaviour; Sex-reversal; Pseudofemale; Tilapia; Oreochromis aureus

\section{Introduction}

Tilapia species present a great potential for aquaculture in tropical and subtropical environment. However, exces-

\footnotetext{
* Corresponding author.

E-mail address: m.ovidio@ulg.ac.be (M. Ovidio).
}

sive and uncontrolled reproduction is a recurring problem in tilapia culture where overcrowding of young causes competition for the available food and represses growth of the entire population (Shelton et al., 1978). This high reproductive efficiency is related to early sexual maturation, prolific spawning and fry care (Philippart and Ruwet, 1982). The aim to control reproduction and improve growth has prompted many studies on this species of high commercial 
interest. Furthermore, male tilapia display better growth capacities than females do. In order to improve production, strategies for the generation of monosex-male populations have been designed for tilapia culture: manual sexing, hybridisation and finally hormonal sex reversal (Tayamen and Shelton, 1979; Chervinsky and Rothbard, 1982; Baroiller et al., 1999, Afonso et al., 2001).

In Oreochromis aureus (homogametic male ZZ), sex reversal of fry with estradiol results in the production of fish characterised by female phenotype and ZZ male genotype, i.e. pseudofemales of the first generation $(\Delta \mathrm{F} 1)$ (Jensen and Shelton, 1979; Mair et al., 1987). Sex reversal treatment with estradiol, applied to monosex male progeny from $\Delta \mathrm{F} 1$, leads to a second generation of pseudofemales $(\Delta F 2)$ (Mélard, 1995). This treatment is repeated to produce successive pseudofemale generations $(\Delta \mathrm{F} 3, \Delta \mathrm{F} 4$, etc.).

Desprez et al. (1994) and Desprez and Mélard (1998) demonstrated that when $\Delta \mathrm{F} 2$ or $\Delta \mathrm{F} 3$ and female $O$. aureus were reared with males in the same spawning tank $\left(5\right.$ fish $\left.\mathrm{m}^{-3}\right)$, the spawning rate of females was higher than that of pseudofemales. Moreover, the percentage of nonspawning pseudofemales was higher than in females. However, pseudofemales presented typical gonads, relative fecundity and mean egg weight similar to females (Desprez et al., 1994). On the other hand, when females and pseudofemales were reared separately, the spawning rate and the percentage of non-spawning individuals were similar in females (genotype WZ) and pseudofemales (genotype ZZ) (Desprez and Mélard, 1998). These observations suggested an influence of the sexual genotype on behaviour in mixed rearing conditions $(\mathrm{F}+\Delta \mathrm{F}+$ males$)$.

The aim of this study was to test this hypothesis. To do so, aggressive behaviour and social status were studied in different fighting experiments $(\mathrm{F} \times \mathrm{F} ; \Delta \mathrm{F} \times \Delta \mathrm{F} ; \Delta \mathrm{F} \times \mathrm{F})$.

\section{Materials and methods}

The $O$. aureus used in this study originated from the Dor station in Israel. This strain has been acclimated since 1979 in the experimental station at Tihange, Belgium. Hulata et al. (1993) confirm that the Dor station stock is derived from the original founders collected in lake Hula (North Israel) around 1958.

In the present study, 37 O. aureus were used: 18 females (F: $446 \pm 96 \mathrm{~g}), 18$ pseudofemales $(\Delta \mathrm{F}: 401 \pm 59 \mathrm{~g})$ and one mature male (M: $365 \mathrm{~g}$ ). Pseudofemales were produced by oral administration of $17 \alpha$-ethynylestradiol $\left(150 \mathrm{mg} \mathrm{kg}^{-1}\right.$ of food) during the early stage of development (Mélard, 1995). Before experiments, the fish were maintained in a 10001 aquarium at $26^{\circ} \mathrm{C}$, under a constant $12 \mathrm{~L} / 12 \mathrm{D}$ photoperiod. During the experiments, they were transferred to different aquaria (see below) and then replaced in the stocking aquarium at the end of the manipulation. Fish were fed daily ad libidum with an artificial pellet diet (34\% protein). In order to recognise each fish individually, different coded incisions were made in the caudal fin. Behaviours were observed and recorded with a remote-controlled cameravideo system.

\subsection{Fighting pair experiments}

In this experiment two randomly selected fish were simultaneously introduced into two isolated parts (opaque partition) of the same 1000-1 aquarium. Two days later, the partition was removed and social status (dominant or subordinate) was determined after $10 \mathrm{~min}$ on the basis of colour and behavioural patterns (lateral display, biting, pursuit, caudal girdle fight and dominance posture) described by Falter (1986). Ten fights, using different females $(\mathrm{F})$ and pseudofemales $(\Delta \mathrm{F})$, were tested for the $\mathrm{FA} \times \mathrm{FB}$ and $\triangle \mathrm{FA} \times \Delta \mathrm{FB}$ combination (the letters $\mathrm{A}$ and $\mathrm{B}$ refer, respectively, to left and right sides of the aquarium where the fish were placed). Twenty-nine different fights were tested for the $\mathrm{F} \times \Delta \mathrm{F}$ combination. Some individuals were used twice, but the recovery period between fights was always $>10$ days. In order to test the maintenance of the dominant state, six of these $29 \mathrm{~F} \times \Delta \mathrm{F}$ fights were replicated using the same pair of individuals, after a 10-d recovery period. In total, $35 \mathrm{~F} \times \Delta \mathrm{F}$ fight were observed. Comparisons of the proportion of dominant and subordinate were tested with contingency tables.

\subsection{Fighting group experiments}

After anaesthesia in a solution of phenoxy-ethanol, $\mathrm{F}$ and $\Delta \mathrm{F}$ were placed in the same aquarium at four different stocking densities: 4, 6 and 8 fish $5001^{-1}$ (respectively, 8, 12 and 16 fish $1000 \mathrm{l}^{-1}$ ) and 10 fish $120 \mathrm{l}^{-1}$ (83 fish $1000 \mathrm{l}^{-1}$ ) with an $\mathrm{F} / \Delta \mathrm{F}$ ratio of $1: 1$. No recording was carried out during the first $10 \mathrm{~min}$. Then, the number of aggressive behaviours, as described by Falter (1986), was recorded and analysed during a 30-min period for each fish of the group. In the 8 fish $1000 \mathrm{l}^{-1}$ density, five tests were carried out using different $\mathrm{F}$ and $\Delta \mathrm{F}$. Three of these combinations were repeated after a 1-week time interval. A total of eight tests were thus performed for the 8 fish $1000 \mathrm{l}^{-1}$ set-up. In the 12 and 16 fish $1000 \mathrm{l}^{-1}$ tests, the original fight was replicated once. The 83 fish $1000 \mathrm{l}^{-1}$ experiment was not replicated because a very high aggressiveness level was observed. Proportions of dominant and subordinate individuals were tested with contingency tables. The comparison of the number of aggressive behaviours produced by $\mathrm{F}$ and $\Delta \mathrm{F}$ was carried out using the Mann-Whitney U-test.

In a second series of experiments, $\mathrm{F}$ and $\Delta \mathrm{F}$ were placed (after anaesthesia in a solution of phenoxy-ethanol) in a 650-1 aquarium, in the presence of a male separated by a transparent partition. Three stocking densities were tested: $2 \mathrm{~F}+2 \Delta \mathrm{F}$ and 1 male (noted $\mathrm{M}$ ) (7.7 fish $1000 \mathrm{l}^{-1}$ ); $3 \mathrm{~F}+3 \Delta \mathrm{F}$ and 1 male $\left(10.7\right.$ fish $\left.1000 \mathrm{l}^{-1}\right) ; 4 \mathrm{~F}+4 \Delta \mathrm{F}$ and 1 male (13.8 fish $\left.1000 \mathrm{l}^{-1}\right)$. After $10 \mathrm{~min}$ with no recording, the biting behaviours between $\mathrm{F}$ and $\mathrm{M}$ and $\Delta \mathrm{F}$ and $\mathrm{M}$ 


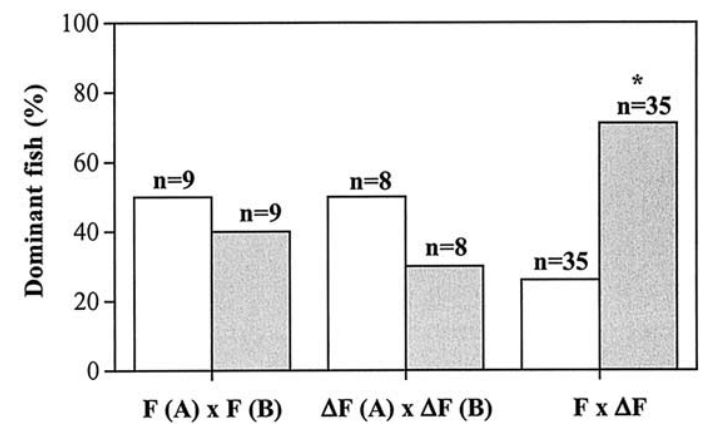

Fig. 1. Percentage of dominant fish in pairs of randomly selected $\mathrm{F}$ and/or $\Delta \mathrm{F}$ introduced to each other by removal of an opaque partition dividing the aquarium. Letters A and B refer, respectively, to left and right sides of the aquarium where the fish were placed. * Significant results $(P<0.05$ contingency table).

through the transparent partition were counted during a 30 -min period. The original experiment was repeated in each stocking density. The number of aggressive behaviours (biting) produced by $\mathrm{F}$ and $\Delta \mathrm{F}$ towards $\mathrm{M}$ were compared using the Mann-Whitney U-test.

\section{Results}

\subsection{Fighting pair experiments (Fig. 1)}

When the opaque partition was removed, the two fish began to fight and one fish generally dominated the other. In the $\mathrm{FA} \times \mathrm{FB}$ and $\triangle \mathrm{FA} \times \Delta \mathrm{FB}$ combinations, one and two fights never produced a well-defined outcome, respectively. In FA $\times \mathrm{FB}$ and $\Delta \mathrm{FA} \times \Delta \mathrm{FB}$ fights, no statistical difference was observed in the percentage of dominant fish (Fig. 1) between the right and the left side of the aquarium. In the $\mathrm{F} \times \Delta \mathrm{F}$ fights, the $\Delta \mathrm{F}$ turned out to be dominant in $74 \%$ $(n=26)$ of the cases and the females in 26\% $(n=9$ $\left(P<0.05, \chi^{2}=4.441\right)$. The six replicates always produced the same results as the original fight.

\subsection{Fighting group experiments}

In the group experiments, the average number of aggressive behaviours (lateral display, biting, pursuit) of $\mathrm{F}$ and $\Delta \mathrm{F}$ in each stocking density indicated that $\Delta \mathrm{F}$ were significantly more aggressive than the females in groups of 12 fish $1000 \mathrm{l}^{-1}$ and 83 fish $1000 \mathrm{l}^{-1}(P<0.05$, Mann-Whitney U-test, Fig. 2a). Similar results were observed in the other two groups, but differences were not significant.

Linear regression indicated that the differences between the number of aggressive behaviours produced between $\Delta \mathrm{F}$ and $\mathrm{F}$ are positively correlated with the stocking density $\left(R^{2}=0.969 ; P=0.016\right)$.

In the $3 \mathrm{~F}+3 \Delta \mathrm{F}+\mathrm{M}$ and $4 \mathrm{~F}+4 \Delta \mathrm{F}+\mathrm{M}$ stocking densities, the counts of biting behaviour towards the transparent partition indicated that $\Delta \mathrm{F}$ were significantly more aggressive towards the male (biting) than the $\mathrm{F}$ were $(P<0.05$,
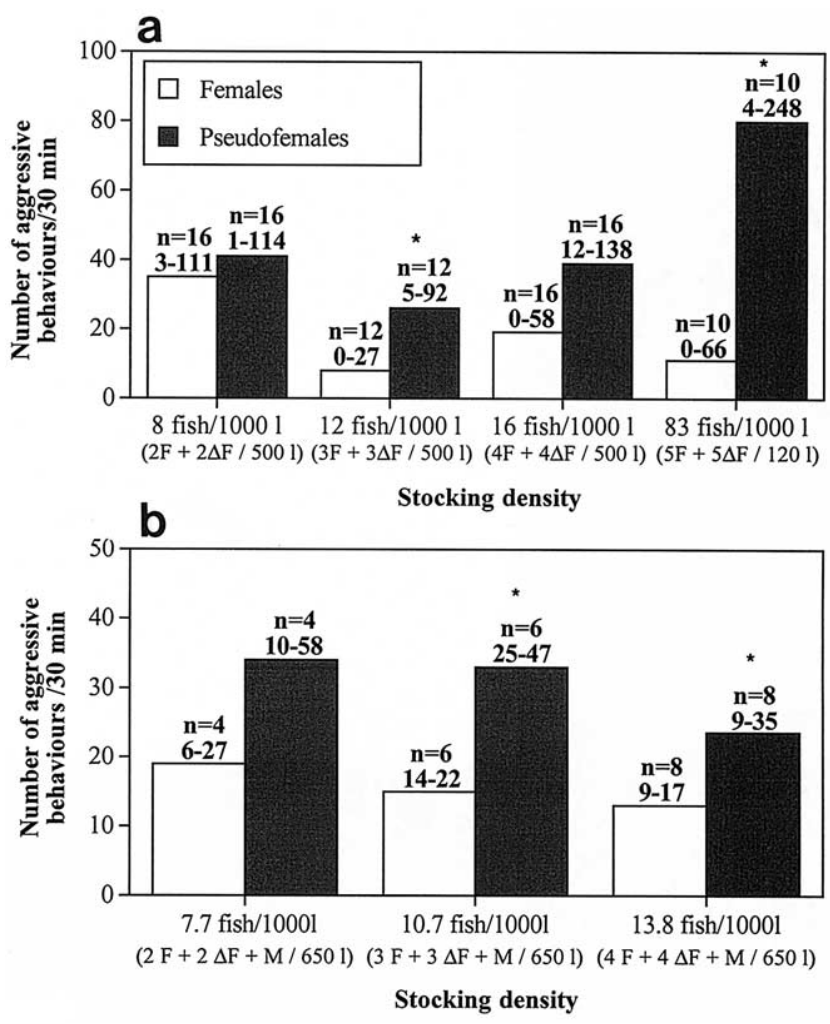

Fig. 2. (a) Average number of aggressive behaviours (lateral display, biting, pursuit) produced by the randomly selected $\mathrm{F}$ and the $\Delta \mathrm{F}$ during $30 \mathrm{~min}$, at four different stocking densities.* Significant results $(P<0.05$ for the 12 fish $1000 \mathrm{l}^{-1}$ stocking density; $P<0.01$ for the 83 fish $1000 \mathrm{l}^{-1}$ stocking density; Mann-Whitney U-test). (b) Average number of aggressive behaviours produced in 30 min by randomly selected $\mathrm{F}$ and $\Delta \mathrm{F}$ towards a male placed behind a transparent partition at three different stocking densities. * Significant results $(P<0.05$; Mann-Whitney U test $)$.

Mann-Whitney U-test). In the $2 \mathrm{~F}+2 \Delta \mathrm{F}$ stocking density, the difference was not significant (Fig. 2b).

\section{Discussion}

Our results suggest that when pseudofemales and females were kept together in the same aquarium, pseudofemales were generally more aggressive and dominant than females. Pseudofemales also seemed to be more aggressive towards males than the females were. The results are reinforced by the weight disadvantage of pseudofemales with respect to females, which would suggest a different fight outcome (Schwanck, 1980). This difference of aggressiveness between females and pseudofemales tended to increase with stocking density. In aquarium, reproduction experiments (Ovidio, unpublished results) indicate that pseudofemales never develop complete sexual display with the male and only produce eggs, which are never fertilised by the male. Our results could probably account for the lower reproductive investment observed in pseudofemales of the second and first generation held in high density spawning tanks (Desprez et al., 1994; Desprez and Mélard, 1998). Similar 
results on spawning frequency were also observed on Oreochromis niloticus, an XX homogametic female species. When XX females were placed with XY pseudofemales in the same spawning tank with males, the cumulative spawning rate of $\mathrm{F}$ and $\Delta \mathrm{F}$ was lower than in tanks containing only males and F (Mélard et al., unpublished results). Some authors (MacBay, 1961; Mires, 1982) have suggested that tilapia populations contain dominant females that spawn more frequently than subordinates, and that the sexual display, which leads to the spawning act, is always preceded by a dominant state characterised by a higher level of aggressiveness (Monfort and Ruwet, 1968). The female then shows a submission state associated with spawning. With respect to the pseudofemales, our results suggest that the level of aggressiveness seems to be too high to evolve into reproductive behaviour and spawning.

Behavioural deviations in relation to hormonal treatment have been observed by different authors. In the Azorean rock-pool blenny Parablennius sanguinolentus, androgen(17 $\alpha$-methyltestosterone and 11-ketotestosterone) treated satellite males developed male secondary sex traits, such as longer and wider male-type genital papilla and anal glands that secrete pheromone. But in terms of behaviour, treated individuals were less aggressive both in front of a mirror and toward females when these latter were introduced into their tanks (Oliveira et al., 2001). In Tilapia macrocephalus (Levy and Aronson, 1955), the treatment of castrated males with one or another androgen can restore gonads and secondary sexual features, and such fish may display part or the entire sequence of courtship activity. Johns et al. (1969), observed that castrated male gourami, Trichogaster trichopterus, on being treated with methyltestosterone, acquired secondary sexual characteristics, but the level of sexual behaviour was not equal to that of the intact males. Castrated Platypoecilus maculatus, when treated with testosterone, developed gonopodia and performed lateral display, which is common to both males and females and represents the first phase of courtship. But the treated fish failed to display the zigzag dance and mating activity typical of an intact male (Pandian and Sheela, 1995). After treatment with estrone, ovariectomised females of $T$. trichopterus remained unattractive to males (Johns et al., 1969). When treated with testosterone propionate, Colisa labiosa females induced male coloration, but not other male characteristics like nest building and defence (Forselius, 1957).

Different studies have indicated that sex inversion with $17 \alpha$-ethynylestradiol sometimes produces intersexuality (Cichlidae: Varadaraj, 1989; Poecilidae: Kavumpurath and Pandian, 1990) or sterility (Meriwether and Torrans, 1986). But in our study, the distinction between females and pseudofemales would not result from a problem of sterility or differences between the general body or gonad morphology, or from the gonadosomatic index of females and pseudofemales (Desprez et al., 1994). Neat et al. (1998) observed that in Tilapia zillii, relative gonad weight is a strong predictor of fight outcome, but in our study, no differences of this type were observed between $\mathrm{F}$ and $\Delta \mathrm{F}$. Desprez and Melard (1998) indicated that when F3 and $\Delta F 3$ are reared separately in spawning tanks, their spawning rates are not different. Desprez (unpublished results) also observed that thyroidal (T3 and T4) and steroidal (testosterone, 11-ketotestosterone, 17- $\beta$ estradiol) hormonal concentrations of the two genotypes are not different. This supports the hypothesis that sex inversion may only be incomplete from the neuroanatomical and/or neurophysiological point of view.

Iwamatsu (1999) demonstrated that when Oryzias latipes embryos $0-6 \mathrm{~d}$ after fertilisation were immersed in saline solution containing estradiol-17ß at $1 \mu \mathrm{g} \mathrm{m}{ }^{-1}$ for only 4-10 d until hatching, sex reversal of genotypic males to females was induced. This indicates that the brain differentiation of this species started in the early embryonic stage. Kwon et al. (2001) demonstrated the existence in Oreochromis niloticus of an aromataze activity during the 3- and 4-d post-fertilisation period in both sexes. In our study, the O. aureus pseudofemales were sex reversed during the larval stage (10-50 d post-fertilisation) and we hypothesise that they may have developed a male brain during the embryonic stage. This difference could account for the behavioural differences observed between females and pseudofemales. This kind of study has been well developed in birds and mammals (review in Schumacher and Balthazart, 1986). It appears that females are less sensitive than males to the activating effects of testosterone on behaviour. This dimorphism is due to the permanent organising actions of gonadal steroids on the brain during early development. The sexual dimorphism affecting brain sensitivity to hormones has been related to sex differences in neuroanatomy and brain receptors levels (Schumacher and Balthazart, 1986).

In conclusion, the present study suggests that hormonal sex reversal of $O$. aureus during the larval stage produced individuals showing abnormal behaviour. This emphasises the importance of the genotype on social, antagonistic and spawning behaviour of Cichlidae. Similar studies on pseudofemales produced by hormonal sex reversal during the embryonic stage should be conducted in the future.

\section{Acknowledgements}

This research was carried out with the financial assistance from the Belgian FNRS (Fonds National de la Recherche Scientifique, contract no. 94584 91). The authors thank Dr. J.C. Philippart, for his contributions to this study and S. Houbart and J.M. Humpers for their technical assistance. 


\section{References}

Afonso, L.O.B., Wasserman, G.J., De Oliveira, R.T., 2001. Sex reversal in Nile tilapia (Oreochromis niloticus) using a nonsteroidal aromatase inhibitor. J. Exp. Zool. 290, 177-181.

Baroiller, J.F., Guiguen, Y., Fostier, A., 1999. Endocrine and environmental aspects of sex differentiation in fish. Cell. Mol. Life Sci. 55, 910-931.

Chervinsky, J., Rothbard, S., 1982. An aid in manually sexing tilapia. Aquaculture 26, 389.

Desprez, D., Mélard, C., Philippart, J.C., 1994. Production of high percentage male offspring with $17 \alpha$-ethynyloestradiol sex reversed Oreochromis aureus: II. Comparative reproductive biology of females and F2 pseudofemales and large scale production of male progenies. Aquaculture 130, 175-190.

Desprez, D., Mélard, C., 1998. Influence du génotype sexuel sur les caractéristiques de la reproduction de femelles (génotype WZ) et de pseudofemelles (génotype ZZ) chez le tilapia Oreochromis aureus. Aquat. Living Resour. 11, 145-153.

Falter, U., 1986. Fluctuations journalières dans le comportement territorial chez Oreochromis niloticus (Teleostei: Cichlidae). Ann. Soc. R. Belg. 2, 175-190.

Forselius, S., 1957. Studies on anabantid fishes. Zool. Bidr. Uppsala 32, 593-597.

Hulata, G., Wolfarth, G.W., Karplus, I., Schroder, G.L., Harpaz, S., Halevy, A., Rothbard, S., Cohan, S., Israel, I., Kavessa, M., 1993. Evaluation of Oreochromis niloticus $\times$ Oreochromis aureus hybrid progeny of different geographical isolates, reared under varying management regimes. Aquaculture 115, 253-271.

Iwamatsu, T., 1999. Convenient method for sex reversal in a freshwater teleost, the Medaka. J. Exp. Zool. 283, 210-214.

Jensen, G.L., Shelton, W.L., 1979. Effects of estrogens on Tilapia aurea: implication for production of monosex genetic male Tilapia. Aquaculture $16,133-242$

Johns, L.S., Lilely, N.R., Seghens, B.H., 1969. The effects of gonadectomy on the reproductive behaviour of the blue gourami, Trichogaster trichopterus (cited in Hoar, W.S.,1969) Reproduction. In: Hoar, W.S., Randall, D.J. (Eds.), Fish Physiology, Vol. 3. Academic Press, New York, pp. 1-72.

Kavumparth, S., Pandian, T.J., 1990. Induction of triploid in the zebra fish Brachydanio rerio. Aquac. Fish. Manag. 21, 219-306.

Kwon, J.H., McAndrew, B.J., Penman, D.J., 2001. Cloning of brain aromataze gene and expression of brain and ovarian aromatase genes during sexual differentiation in genetic male and female nile tilapia Oreochromis niloticus. Mol. Reprod. Dev. 59, 359-370.

Levy, M., Aronson, L.R., 1955. Morphological effects of castration and hormone administration in the male cichlid fish Tilapia macrocephala. Anat. Rec. 122, 450-451.
Mac Bay, L.G., 1961. The biology of Tilapia nilotica (Linnaeus). Proc. Ann. Conf. Southeast Assoc. Game Fish Comm. 15, 208-218.

Mair, G.C., Penman, D.J., Scott, A., Skibinski, D.O.F., Beardmore, J.A., 1987. Hormonal sex reversal and the mechanisms of sex determination in Oreochromis. Proc. World Symp. Selection, Hybridisation and Genetic Engineering in Aquaculture, Vol. 2, pp. 27-30.

Mélard, C., 1995. Production of high percentage of male offspring with $17 \alpha$-ethynyloestradiol sex reversed Oreochromis aureus: I. Estrogen sex-reversal and production of F2 pseudofemales. Aquaculture 130, $25-34$.

Meriwether, F.H., Torrans, E.K., 1986. Evaluation of new androgen (mibolerone) and procedure to induce functional sex reversal in tilapia. In: Mclean, J.L., Dizon, L.B., Hosillos, L.V. (Eds.), Proc. First Asian Fish. Soc. Manila, Philippines. pp. 675-678.

Mires, D., 1982. A study of the problem of mass production of hydrid Tilapia fry. In: Pullin, R.S.V., Lowe-McConnel, R.H. (Eds.), The Biology and Culture of Tilapia, ICLARM Conference Proceeding 7, Manilla, Philippines. pp. 317-329.

Monfort, A., Ruwet, J.C., 1968. Patrons moteurs et mouvements d'expression chez les Tilapia rendalii (Boulenger, 1896) et Tholloni congica (Poissons Cichlidés). Rev. Zool. Bot. Afr. 77 (1-2), 59-68.

Neat, F.C., Huntingford, F.A., Beveridge, M.M.C., 1998. Fighting and assessment in male cichlid fish: the effects of asymmetries in gonadal state and body size. Anim. Behav. 55, 883-891.

Oliveira, R.F., Carneiro, L.A., Canario, A.V.M., Grober, M.S., 2001. Effect of androgens on social behaviour and morphology of alternative reproductive males azorean rock-pool blenny. Hormone Behav. 39, $157-166$.

Pandian, T.J., Sheela, S.G., 1995. Hormonal induction of sex reversal in fish. Aquaculture 138, 1-22.

Philippart, J.C., Ruwet, J.C., 1982. Ecology and distribution of tilapias. In: Pullin, R.S.V., Lowe-Mc Connel, R.H. (Eds.), The Biology and Culture of Tilapia, ICLARM Conference Proceeding 7, Manilla, Philippines. pp. $15-59$.

Schwanck, E., 1980. The effect of size and Hormonal state on the establishment of dominance in young males of Tilapia-Mariae (Pisces, Cichlidae). Behav. Processes 5, 45-53.

Shelton, W.L., Hopkins, K.D., Jensen, G.L., 1978. Use of hormones to produced monosex Tilapia for aquaculture. In: Smitherman, R.O., Shelton, W.L., Grover, S.H. (Eds.), Culture of Exotic Fishes Symposium Proceedings. Fish Culture Section. Am. Fish. Soc. Auburn. pp. 10-33.

Schumacher, M., Balthazart, J., 1986. Testosterone-induced brain aromatase is sexually dimorphic. Brain Res. 370, 285-293.

Tayamen, M.M., Shelton, W.L., 1979. Inducement of sex reversal in Sarotherodon niloticus (Linnaeus). Aquaculture 14, 349-354.

Varadaraj, K., 1989. Feminization of Oreochromis mossambicus by the administration of diethylstilbestrol. Aquaculture 80, 337-341. 